Article

\title{
Changes in Temperature and Moisture Content of an Extensive-Type Green Roof
}

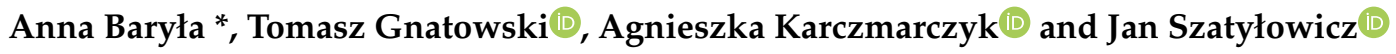 \\ Department of Environmental Improvement, Faculty of Civil and Environmental Engineering, Warsaw \\ University of Life Sciences (SGGW), Nowoursynowska 159, 02-776 Warsaw, Poland; \\ tomasz_gnatowski@sggw.pl (T.G.); agnieszka_karczmarczyk@sggw.pl (A.K.); jan_szatylowicz@sggw.pl (J.S.) \\ * Correspondence: anna_baryla@sggw.pl
}

Received: 11 March 2019; Accepted: 25 April 2019; Published: 29 April 2019

\begin{abstract}
Green roofs ought to be perceived as ensuring a wide-ranging contribution to the sustainable urban environment. The aim of the study was; (1) to investigate and analyse the differences in the surface temperature between four models of green roofs of the extensive type and a conventional roof (covered with bitumen) under the conditions of a continental climate; (2) to assess the influence of environmental parameters (climatic water balance, air temperature, relative humidity, moisture content in the profile) on changes in the temperature of the extensive type green roof profile (substrate and vegetation mat). The study (1) was carried out during the period of June-December 2016 using a thermal imaging camera. As a result, the greatest differences in temperature were noted in June and July, with a maximum difference between the temporary surface temperature of a green roof and a conventional roof of up to $24^{\circ} \mathrm{C}$. The (2) study was conducted on a green roof profile with sedum plant vegetation. The measured parameters were: the temperature of the surface, the temperature and humidity at depths of $3 \mathrm{~cm}$ and $15 \mathrm{~cm}$, and active radiation in the photosynthesis process (PAR). As the result, the range of daily changes in the surface temperatures and the vegetation mat were higher than the range of changes in the air temperature. Atmospheric precipitation decreased the thermal gradient in the soil, as well as the temperature fluctuations in the course of a day as a result of the increase in humidity following a rainfall. During the summer period, over the course of a day, the surface temperature was $5^{\circ} \mathrm{C}$ higher than the air temperature. The largest correlation was obtained between the air temperature and the temperature of the surface as well as the temperature of the structural layers.
\end{abstract}

Keywords: extensive green roof; temperature in profile; moisture; evapotranspiration; rainfall

\section{Introduction}

In 2008, for the first time in history, half of planet Earth's population resided in cities, whereas in the EU three-quarters of the population already fall into this category [1]. Currently, large cities are facing problems of smog and the consequences of climate change- the phenomena of urban heat islands, storms, urban flooding and flash floods [2-4]. These phenomena are a threat to the inhabitants of cities and can generate measurable losses. In addition to the risk of flooding, extreme temperatures may also be dangerous. Climate changes, urbanization and the increased population density of cities has led to an increase in the frequency and intensiveness of heat waves [5]. Considering all of the negative effects of extreme heat, there is a real need to take actions aimed at decreasing the outside temperature in urban areas. An increase in green areas (so-called green infrastructure) has been found to be an effective way of lowering the temperature in cities [6,7]. Green roofs represent one of the possible measures that can be taken to achieve achieving this aim [8-10]. Many studies have indicated the potential benefits of green roofs to the internal environment of a building, such 
as energy savings [11,12] or lowering the temperature in rooms by a few degrees [13]. One of the advantages of green roofs is the protection of the structural layers of the roof against solar radiation, enabling the lowering of temperature and minimizing temperature fluctuations. A traditional roof cover absorbs solar radiation during the day, leading to an increase in temperature, which falls in the evening along with the lowering of air temperature. Daily temperature fluctuations cause thermal stresses in materials and decrease their durability. Green roofs minimize temperature fluctuations by creating a barrier between solar radiation and structural layers. Studies carried out by [14] in Ottawa, Canada, showed that following 22 months of observation, the median temperature fluctuations in an uncovered roof membrane were $42-47^{\circ} \mathrm{C}$, whereas a green roof reduced temperature fluctuations in the roof membrane to a median of $5-7^{\circ} \mathrm{C}$ the entire year. In addition to thermal aspects, there are many other arguments supporting the application of green roofs, terraces and walls on a large scale in urban areas: they counteract climate changes and reduce the emission of $\mathrm{CO}_{2}$ into the atmosphere, nullify the negative effects of urbanization, reduce smog [15-17], retain rainwater and delay runoff [18-21], suppress noise, create friendly living and leisure space, and improve the aesthetics of buildings [22,23]. In Poland, work is currently in progress on preparing urban adaptation plans for climate change in which green roofs are among the basic adaptation strategies. Structurally speaking, green roofs comprise a series of layers: a waterproof membrane on the roof, a drainage system, a substrate layer and plants [24,25]. The type of substrate and its depth play an important role in green roofs [26,27]. The substrate is a specific and modified mixture, which is usually lighter than soil, porous, mainly inorganic and capable of sustaining plant growth $[28,29]$. The depth of the substrate can range from a few centimetres to a metre. Depending on the depth of the substrate, the type of plants and irrigation requirements, two types of green roofs can be distinguished, i.e., extensive and intensive.

Extensive green roofs are also referred to as ecological or light roofs, have a substrate layer that is 2-20 cm deep, require minimal or no irrigation, and are usually planted from moss, succulents, grass and certain green plants [24,30]. This type of green roof has the widest range of use, is cost effective and may be implemented on most roofs. Accordingly, it has significant potential for use in Poland, as a tool supporting the improvement of thermal conditions in urban areas. Intensive green roofs are deeper than $20 \mathrm{~cm}$, are often designed as gardens intended for use by people, and usually require irrigation and conservation [24,31]. Extensive green roofs have a higher potential for acceptance than intensive green roofs, in which structural load limits apply. When selecting plants appropriate for extensive green roofs, the priority is tolerance to stress and the cooling properties of the vegetation. A decreased availability of substrate moisture may limit evapotranspiration and cause the warming of leaves, which influences thermal conditions (this can differ between species) [32,33]. A limitation of extensive solutions is the fact that a shallower substrate has a lower and finite ability to retain rainwater [34] and is prone to drying out faster, causing plant stress during long periods of drought. The range of water capacity recovery between events is connected with the evapotranspiration and retention capacity of the profile. These parameters are dependent on the history of rainfall (intensity, duration, time between events), climatic conditions (net radiation, temperature, humidity, wind) vegetation characteristics (species, leaf area index, growth stadium) and the properties of the substrate (porosity, permeability, water-holding capacity) [35-38]. Some of these parameters are strictly connected with the climatic conditions on a local scale. As a consequence, their identification is of high importance from the perspective of assessing green roof operation as well as their proper use [39,40].

The study presented in this paper was performed in two stages. In the first stage, changes in the surface temperature were measured on four models of an extensive green roof and a conventional roof (covered with bitumen) under the conditions of a humid continental climate. The aim of the second stage was to assess how the thermal behaviour of the construction layers of a green roof changed under humid continental climate. Based on the results from the second stage, an analysis of the influence of environmental parameters (CBW, air temperature, relative humidity, wind speed, moisture content in the profile) on changes in the temperature of a green roof profile covered with sedum was performed. 


\section{Materials and Methods}

\subsection{Characteristics of the Test Stands}

Models of extensive green roofs were made in four stands, with one prepared as a control (reference-conventional roof) sample (Figure 1). The dimensions of all stands were $2 \mathrm{~m} / 1 \mathrm{~m} / 0.2 \mathrm{~m}$ (length/width/depth), with the stands tilted at an angle of $2 \%$, and having an inside capacity of $0.4 \mathrm{~m}^{3}$. In each stand, a drainage pipe of $8 \mathrm{~cm}$ in diameter was installed.

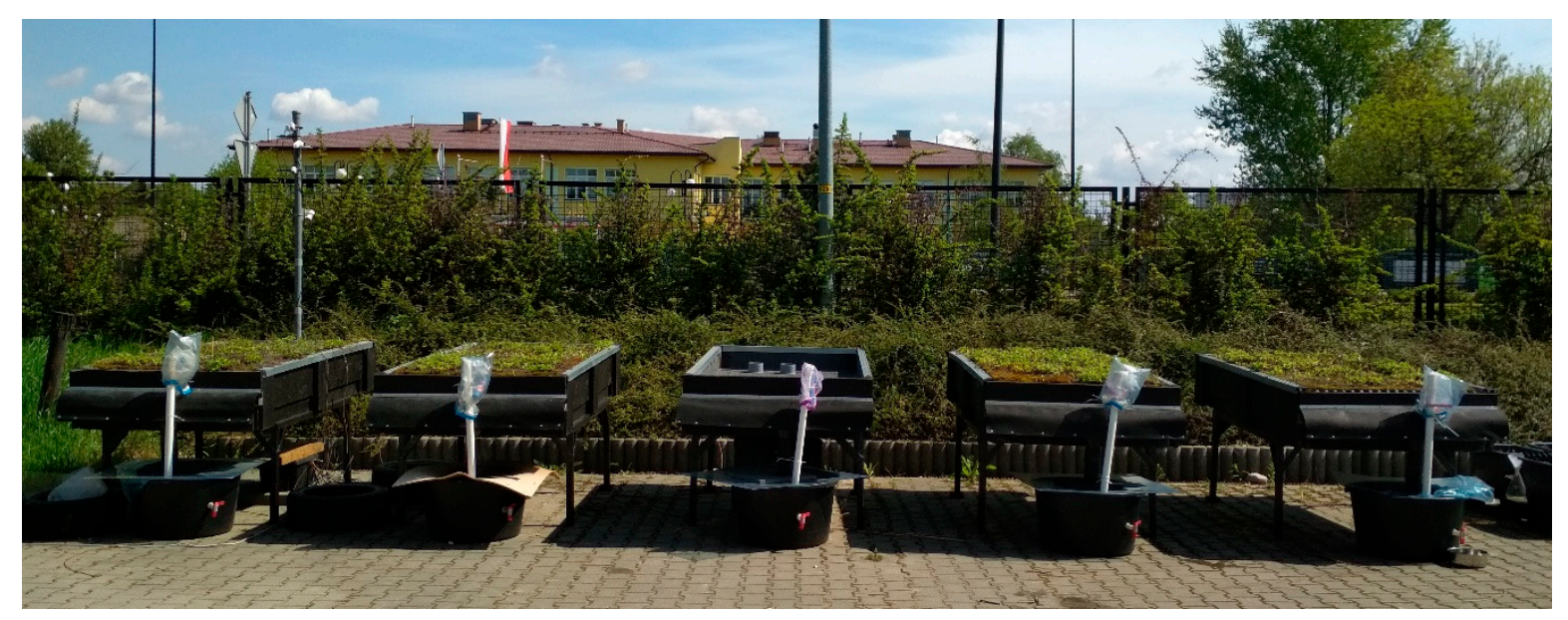

Figure 1. The view of the open air experiment (test stands): green roof models, reference model (in the middle).

The construction of each model consisted of seven layers, (from the bottom to the top): (1) a wooden base; (2) root-resistant hydroisolation; (3) a protective membrane (DuPont Typar SF 32, GRK 2, $110 \mathrm{~g} / \mathrm{m}^{2}$ ); (4) a drainage mat (Terrafond Garden 20, $2 \mathrm{~cm}$ ); (5) a filtration layer (Polyfelt TS 20, GRK 2, $\left.125 \mathrm{~g} / \mathrm{m}^{2}\right)$; (6) $15 \mathrm{~cm}$ of mineral substrate and (7) a prefabricated vegetation mat (2.5 cm layer) Xeloflor XF317 (Table 1). The vegetation mat used in this study is a common solution composed of moss, sedum and herbs. According to the producer, the seed mixture of the vegetation mat comprises: Sedum album, Sedum acre, Sedum kamtschaticum, Sedum spurium, Sedum reflexum, Sedum sexangulare, Dianthus deltoides, Dianthus carthusianorum, and Thymus vulgaris (Xero Flor 2016 personal communication [41]). In this case, only sedum plants survived the first year of test stand operation. In the construction of the green roofs, three types of substrates (Table 1) were applied in accordance with FLL guidelines (2008). In Stand 2 (GR 2), a substrate which had been specially selected in terms of limiting phosphate in runoff was implemented [42]. 
Table 1. Characteristics of the test stands.

\begin{tabular}{|c|c|c|c|c|}
\hline Abbreviated Name & GR1 1 & GR2 2 & GR4, GR5 & RR3 \\
\hline $\begin{array}{l}\text { Extensive vegetation, } \\
2.5 \mathrm{~cm} \text { thick }\end{array}$ & \multicolumn{3}{|c|}{$\begin{array}{l}\text { Precultivated XF317 moss-sedum-herbs vegetation mat (Sedum album, Sedum } \\
\text { acre, Sedum kamtschaticum, Sedum spurium, Sedum reflexum, Sedum sexangulare, } \\
\text { Dianthus deltoides, Dianthus carthusianorum, and Thymus vulgaris). }\end{array}$} & \multirow{5}{*}{ None } \\
\hline $\begin{array}{l}\text { Vegetation layer, } \\
\text {-extensive substrate, } \\
15 \mathrm{~cm} \text { thick }\end{array}$ & $\begin{array}{l}\text { SPG E-E-mixture of } \\
\text { rinsed sand, gravel, } \\
\text { limestone, crushed } \\
\text { brick, broken fine lime, } \\
\text { low peat and compost; }\end{array}$ & $\begin{array}{c}\text { SPG E-M-mixture of } \\
\text { washed sand, gravel, } \\
\text { limestone, crushed red } \\
\text { brick; }\end{array}$ & $\begin{array}{l}\text { SPG E-M-Type } 2 \\
\text { mixture of rinsed sand, } \\
\text { rinsed gravel, } \\
\text { limestone grit, crushed } \\
\text { brick, low peat; }\end{array}$ & \\
\hline Filtration layer & \multicolumn{3}{|c|}{$\begin{array}{l}\text { Polyfelt TS } 20 \text { polypropylene geotextile of GRK } 2 \text { strength class, density of } \\
\qquad 125 \mathrm{~g} / \mathrm{m}^{2}\end{array}$} & \\
\hline Drainage layer & \multicolumn{3}{|c|}{ Terrafond Garden $20 \mathrm{~L}$ drainage mat, $2 \mathrm{~cm}$ height. } & \\
\hline Protective layer & \multicolumn{3}{|c|}{$\begin{array}{c}\text { DuPont Typar SF } 32 \text { polypropylene geotextile with a GRK } 2 \text { strength class } \\
\text { and density } 110 \mathrm{~g} / \mathrm{m}^{2} ;\end{array}$} & \\
\hline Waterproof layer & \multicolumn{4}{|c|}{$\begin{array}{l}\text { Heat sealing tar paper resistant to the growing through of plant roots in accordance with the PN-EN } \\
\text { ISO 13,948 standard; }\end{array}$} \\
\hline Base & \multicolumn{4}{|c|}{ OSB board, $16 \mathrm{~mm}$ in thickness, with cracks not exceeding $5 \mathrm{~mm}$. } \\
\hline
\end{tabular}

\subsection{Analysis of the Surface Temperature of Green Roofs and a Conventional Roof}

Comparisons of the temperature between a conventional roof and green roofs were performed during the period from June to December 2016 on the test stands located at WULS-SGGW Water Centre in Warsaw $\left(52^{\circ} 9^{\prime} 34.475^{\prime \prime} \mathrm{N} 21^{\circ} 3^{\prime} 1.52^{\prime \prime} \mathrm{E}\right)$. For the measurement of surface temperature a thermal imaging camera was used. Thermal images were taken for each test stand six times per month (always during the same hour) in the observation period of seven months. In total, 42 thermal images were collected for each stand. Radiant temperature was measured using a Flir SC620 thermal imaging system operating in the range of 7.5-13 $\mu \mathrm{m}$, which enabled the acquisition of images with a resolution of $640 \times 480$ pixels. With this camera it is possible to obtain full-colour pictures in the visible spectrum and process thermal imaging pictures in a selected colour scale (Photo 2). Individual images were registered on a memory card. The camera was placed at a level of $150 \mathrm{~cm}$ from the surface of the model. The measurement points were marked, and the same distance was maintained for all measurements performed in the subsequent terms. The thermograms registered in a numeric manner were analysed using the FLIR Quick Report 1.2 program. The radiometric temperatures were calculated accounting for the correction of: the actual emission coefficient (the emission coefficient for tar paper was assumed at 0.92 , whereas for soil as well as vegetation cover, the value of 0.95 was assumed [43]). The air temperature was assumed to be the temperature of the surroundings, since the surroundings were the same for the entire test area and this did not affect the differentiation of individual fragments of the test field [43].

In order to compare the radiation temperatures between the test stands, box transects-(white box in Figure 2), each consisting of 2000 points, were indicated on the thermal images. Transects were located in the middle of the width of the roof. On the basis of the radiation temperatures obtained along the measurement boxes, all data were then compiled for each month and analysed. Histograms have been drawn up for a summer day (4 of April 2016) and for a winter day (22 of February 2016). 


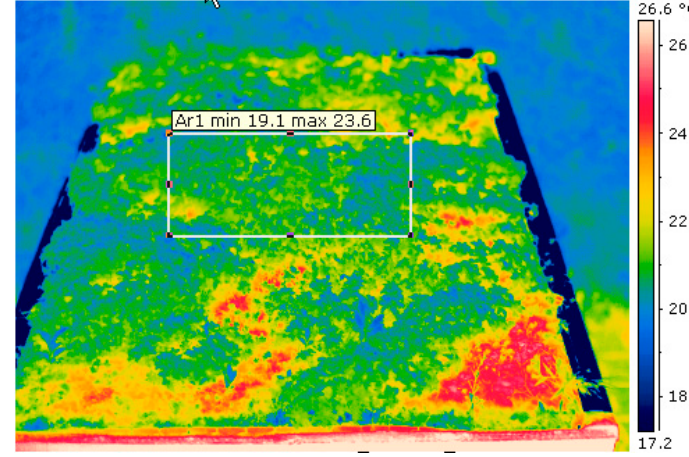

(a)

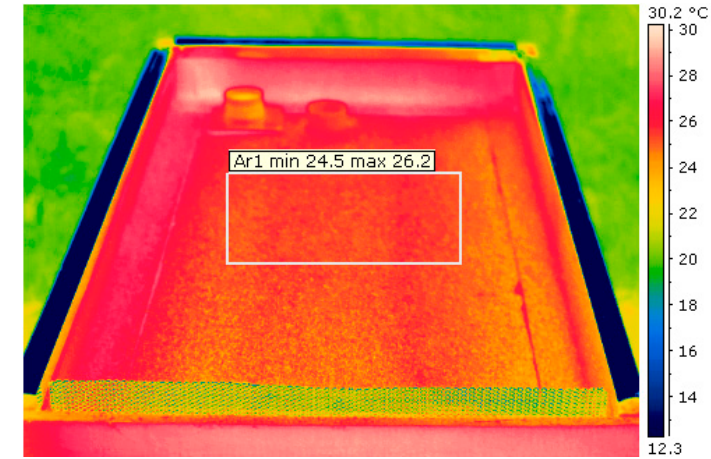

(b)

Figure 2. Thermal image of the green roof models (a) and conventional roof (b) (white box-transects box).

In order to characterize the green roof behaviour in relation to the urban heat island (UHI) phenomenon, the results of the surface temperature analysis have been summarized by the appropriate indexes. Based on the relevant work of $[44,45]$, two indexes were defined, as follows: the first index, called surface temperature reduction (STR), was obtained by the ratio of the surface temperature of the i-th plot to the surface temperature of the reference Plot (the traditional bituminous roof). The STR can be evaluated in terms of average values (subscript av) or maximum values (subscript max):

$$
S T R_{a v}=\frac{T_{a v, i .}}{T_{a v, r e f .}} \quad S T R_{\max }=\frac{T_{\max , i .}}{T_{\max , r e f .}}
$$

The second index, called the external temperature ratio (ETR), was obtained as the ratio of the i-th plot surface temperature to the average temperature of external air. Accordingly, ETR can be evaluated in terms of maximum values (subscript max) and minimum values (subscript min).

$$
E T R_{\max }=\frac{T_{\text {max }, i .}}{T_{a v, a i r}} \quad E T R_{\min }=\frac{T_{\text {min }, i}}{T_{a v, \text { air }}}
$$

The analysed data were collected during June-December 2016.

\subsection{Temperature and Moisture Content Changes in the Layers of The Green Roof}

During the period of Apil-December 2017 and January-March 2018, the second phase of the study regarding the changes in the temperature in the profile of a green roof was carried out on one of the test stands. Additionally in the vegetation period of April-September 2017, the influence of environmental factors (i.e., air temperature, relative humidity, climatic water balance (P-E), moisture content of the vegetation mat and substrate) on temperature changes in the profile was determined. The air temperature, wind speed and air humidity were measured at the meteorological station of the WULS-SGGW Water Centre in Warsaw, situated next to the models of green roofs. The temperature of the surface was measured using a non-contact infrared radiometer (IR type 400) sensor (Apogee Instruments 2013). The temperature and humidity at depths of $3 \mathrm{~cm}$ and $15 \mathrm{~cm}$ were measured using a Decagon Type GS3 needle probe. The probes were placed horizontally at each of the depths. The data were registered at 10-minute intervals using an EM 50 data recorder. Active radiation in the photosynthesis process (PAR) was measured using a photon flux sensor (Model QSO-S) placed at a height of $1 \mathrm{~m}$ next to the model. For the vegetation period in 2017, the climatic water balance (CWB) was calculated [46]. In this study, the CWB was defined as the difference between rainfall $\mathrm{P}$ and $\mathrm{ET}_{\mathrm{o}}$ reference evapotranspiration calculated using the Penman-Monteith equation [38,47];

$$
E T_{o}=\frac{0.408\left(R_{n}-G\right)+\gamma \frac{900}{T+273} u_{2}\left(e_{s}-e_{a}\right)}{\Delta+\gamma\left(1+0.34 u_{2}\right)}
$$




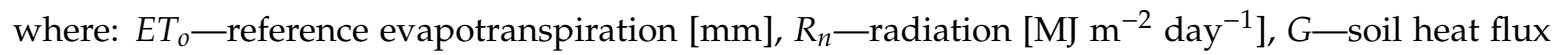
density $\left[\mathrm{MJ} \mathrm{m}^{-2} \mathrm{day}^{-1}\right], T$-average daily temperature measured at a height of $2 \mathrm{~m}\left[{ }^{\circ} \mathrm{C}\right], u_{2}$-wind

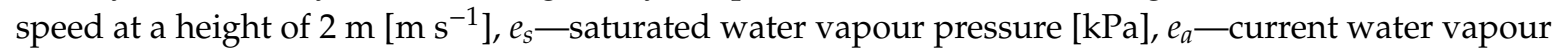
pressure [kPa], $\left(e_{s}-e_{a}\right)$-water vapour pressure deficit, $\Delta$-the slope of the vapour pressure, and $\gamma$-psychrometric constant $\left[\mathrm{kPa}^{\circ} \mathrm{C}^{-1}\right]$ according to the formula in [48].

\subsection{Climatic Conditions}

The climate of Warsaw is a mix of humid and mild sea air and dry and raw continental air (transition climate). Two different air masses pass above the city and are exchanged at a high frequency, which causes variable weather. The average annual air temperature is $7-8{ }^{\circ} \mathrm{C}$, with the minimum temperature reached in January and the maximum reached in July. There are approximately 40 hot days, with the average temperature above $25^{\circ} \mathrm{C}$. The annual rainfall is approximately $520 \mathrm{~mm}$, with the maximum rainfall in July and the minimum in February. Warsaw is covered in snow for 50-60 days a year and the number of frosty days (average temperature below $0{ }^{\circ} \mathrm{C}$ ) is 33 . The average wind speed in the city is approximately $4 \mathrm{~m} \mathrm{~s}^{-1}$ [49].

\subsection{Statistical Analyses}

Normality was assessed using the Shapiro-Wilk test. As the values of temperature and moisture content are not normally distributed, their values were subjected to analysis using the Kruskal-Wallis test. The Spearman rank coefficient was used to determine the relationship between the temperature content in the individual layers and the moisture content in the layers, radiation, wind speed, relative humidity, air temperature and CWB. All statistical analyses were carried out using STATGRAPHICS Centurion XVI software.

\section{Results}

\subsection{Comparing the Temperature of a Green Roof and Conventional Roof}

The first phase of the study performed during the June-September period of 2016 showed that the average surface temperatures of green roofs were $25.7-26.9^{\circ} \mathrm{C}$, whereas it was $32.6^{\circ} \mathrm{C}$ for the roof covered with bitumen. The Kruskal-Wallis test showed statistically significant differences between the individual group medians during June-December $(p=0.00)$. During the November-December period, the average temperature of the green roofs ranged from $5.4-5.8^{\circ} \mathrm{C}$, and $6.6^{\circ} \mathrm{C}$ for the conventional roof. At a minimum air temperature of $-3{ }^{\circ} \mathrm{C}$, the average temperature of the green roofs was $3{ }^{\circ} \mathrm{C}$, but $-5.9^{\circ} \mathrm{C}$ for the conventional roof counterpart. Green roofs with a varied substrate layer composition (GR1-GR5) did not show significant differences in the temperature of the top layer. The average increase in the temperature difference between the green roof models during the July-September period was $1.2^{\circ} \mathrm{C}$, whereas for the November-December period, it was $0.4^{\circ} \mathrm{C}$.

The use of the previously defined indexes enabled comparison between the temperature changes of the tested green roofs and the conventional roof. Both indexes were obtained as average values calculated in the analysed month. The red dotted line represents the threshold at which the green roofs behave like a reference roof with a STR coefficient equal to one (Figure 3). During the summer, both the average and maximum surface temperature of green roofs were significantly lower than the conventional roof, because STRav and STRmax were invariably smaller than the unit value. The smallest values of STRmax were achieved in June and July and were similar in the case of the four green roofs. The maximum ratios did not exceed 0.70 for the four surfaces (Figure $3 b$ ). The maximum temperatures of the surfaces of green roofs 1 and 2 were higher in the summer months than green roofs 4 and 5. The highest average values of 0.89-0.94 were observed in September. The maximum STR values were obtained in November (0.78-0.94) and were lower than the reference roof. 

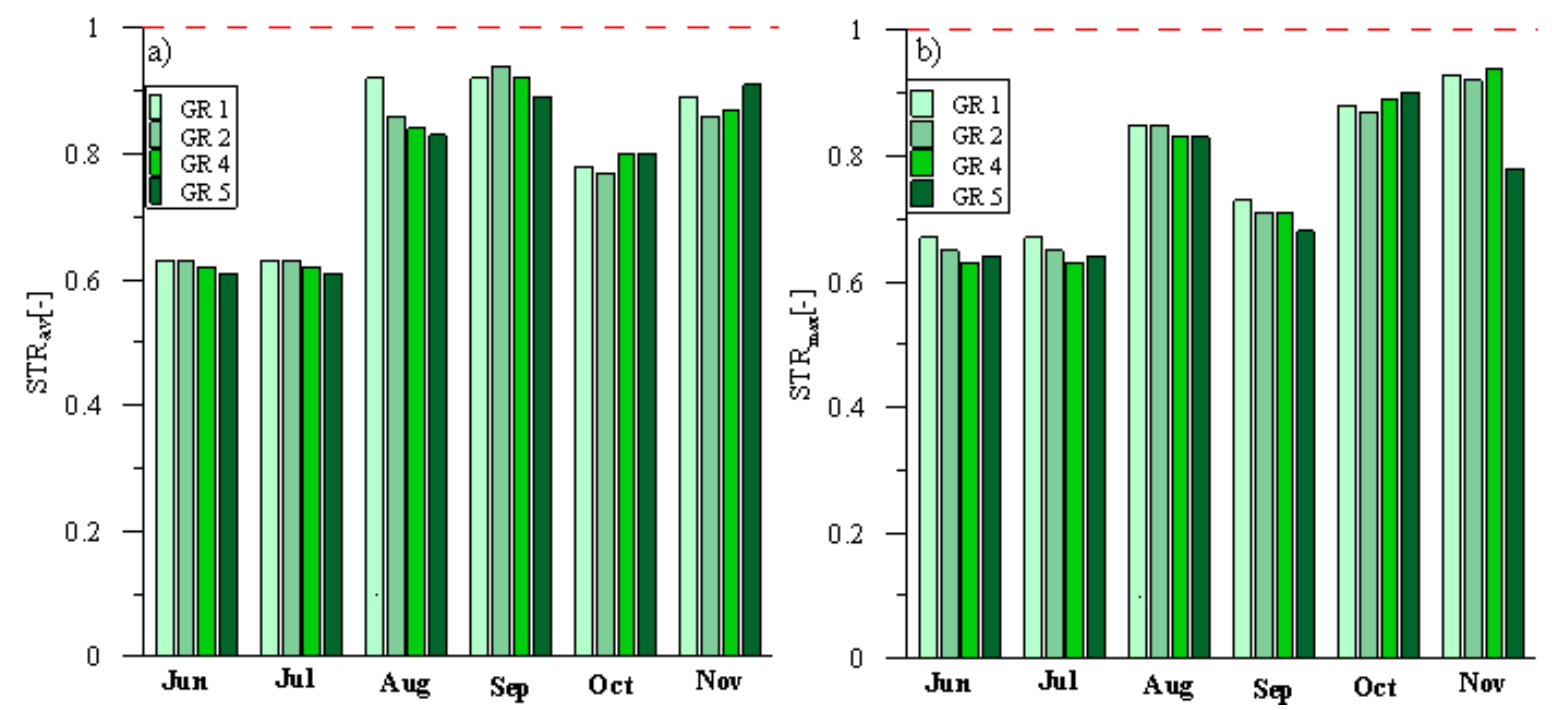

Figure 3. Monthly average daily values of (a) SRTav and (b) STRmax for the four green plots, (GR1-GR5-green roof models, RR3.- reference roof).

A comparison of surface temperature and external air temperature, characterized by the ETR index, is shown in Figure 4. In June and July, the surface temperature of conventional roof was much higher (ETRmax $=2.3$ in July) than the temperature of an air and green roofs (ETRmax $=1.6$ in July) (Figure 4a). The smallest differences between an air temperature, surface of the conventional roof and surface of green roofs were observed in August-September. In September, the temperature of green roofs was close to the air temperature $($ ETRmax $=1.1$, while ETRmin $=0.7)$. In November, the largest differences between ETRmin and ETRmax were observed in case of both, the conventional roof and green roofs.
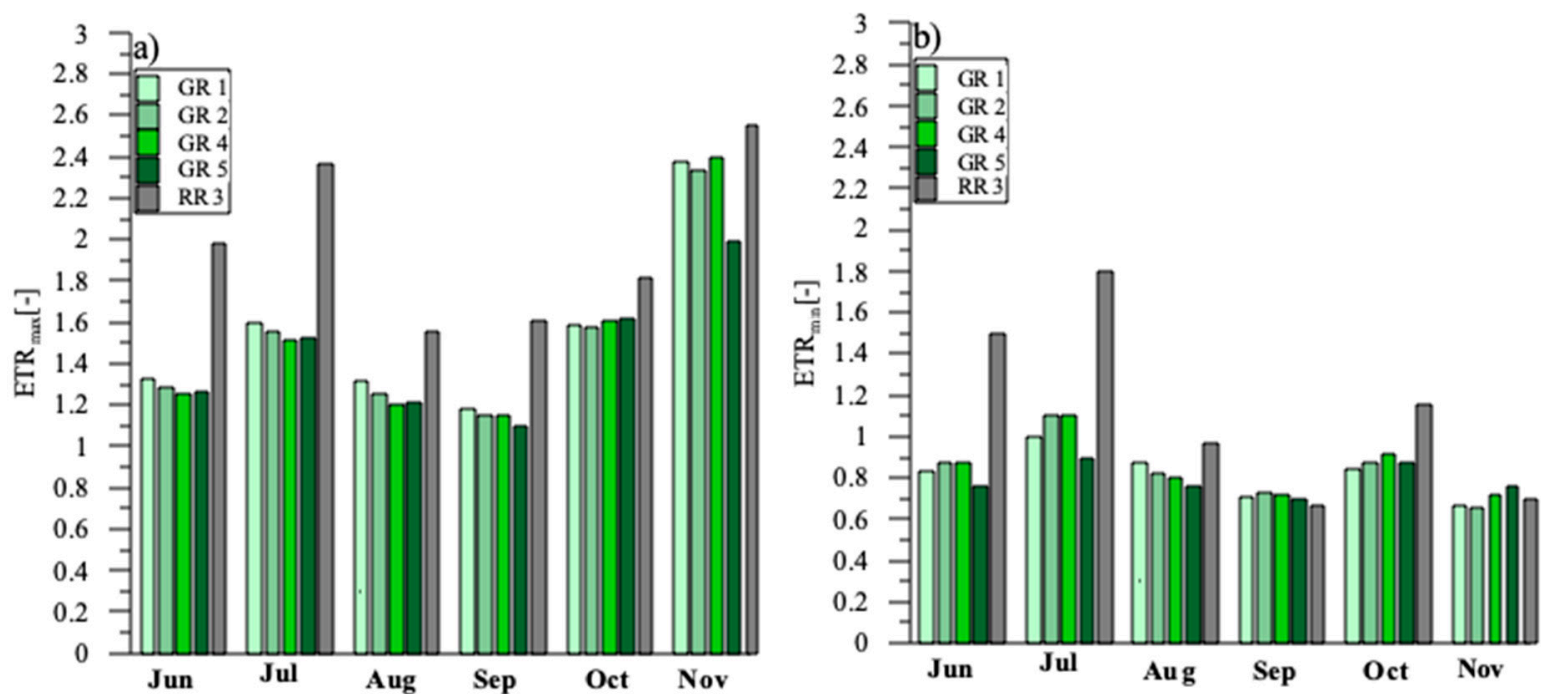

Figure 4. Monthly average daily values of (a) ETRmax and (b) ETRmin for the four green plots (GR1-GR5-green roof models, RR3-reference roof).

The selected two histograms of the warmest and coldest day in the course of this research showed that in July, the difference between surface temperature of the green roof and the conventional roof is significant, while in December the differences are small (Figure 5). On the 4 of July, with an air temperature of $30^{\circ} \mathrm{C}$, the average temporary temperature of the green roof was $27.0^{\circ} \mathrm{C}\left(\max 33^{\circ} \mathrm{C}\right)$ and the conventional roof was $52.6^{\circ} \mathrm{C}$ (Figure 5a). In contrast, in December the average temporary temperature of the green roof was $-3.8^{\circ} \mathrm{C}$ and the conventional roof was $-5.3^{\circ} \mathrm{C}$ (Figure $5 b$ ). 

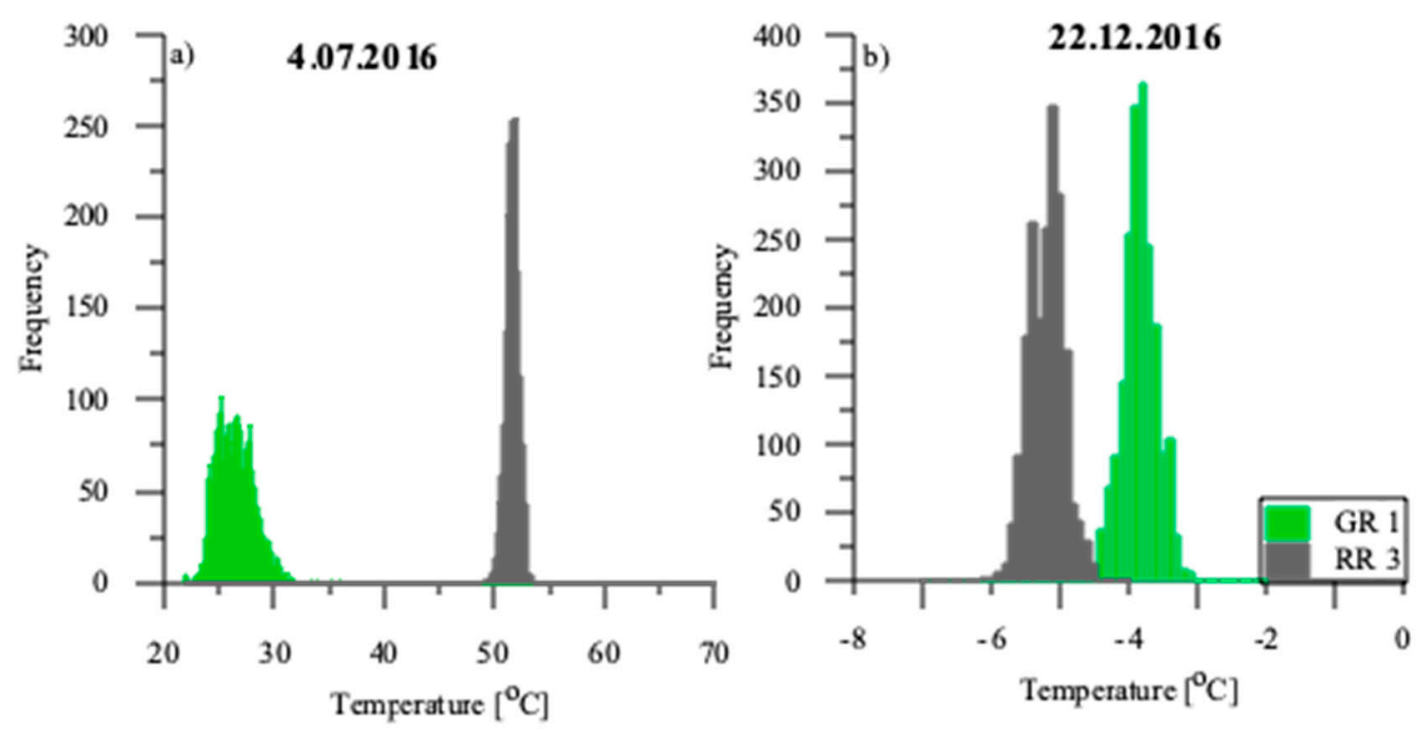

Figure 5. The frequency of the surface temperature on (a) the 4 of July 2016 and (b) the 22 of December 2016 (GR1 green roof, RR3-reference roof). The frequency distribution histogram is plotted vertically as a chart with bars that represent numbers of observations temperature in white box within certain ranges (bins) of values.

\subsection{Analysis of Changes in the Moisture Content and Temperature of a Green Roof Profile}

The yearly course of temperature in a green roof profile (GR1) showed a high convergence with the air temperature trends (Figure 6). The average yearly air temperature was $9.8^{\circ} \mathrm{C}$, the average temperature of the active surface was $10.2{ }^{\circ} \mathrm{C}, 10.9^{\circ} \mathrm{C}$ for the vegetation mat, and $11.1{ }^{\circ} \mathrm{C}$ for the substrate. In the spring period ( 1 of April 2017-30 of June 2017), the measurements showed that the highest average temperature occurred in the vegetation mat $\left(16.7^{\circ} \mathrm{C}\right)$ and fell with increasing depth $\left(16.1^{\circ} \mathrm{C}\right)$. The average temperatures in the green roof profile were higher than the average air temperature $\left(13.9^{\circ} \mathrm{C}\right)$ by $2.8^{\circ} \mathrm{C}$, in the vegetation mat and by $2.2^{\circ} \mathrm{C}$ in the substrate. During the summer period ( 1 of July-30 of September), the pattern of the average temperature distribution was similar to that of the spring period. The highest average temperature occurred in the vegetation mat $\left(19.2^{\circ} \mathrm{C}\right)$ and decreased along with depth, while the average temperature of the substrate was $19.0^{\circ} \mathrm{C}$. The active surface in the summer period increased in temperature to $18.5^{\circ} \mathrm{C}$ at an average air temperature of $17.9^{\circ} \mathrm{C}$. In the summer and spring periods, over the course of a day the temperature of the active surface was the highest, which was caused by the most intensive supply of solar radiation [50].

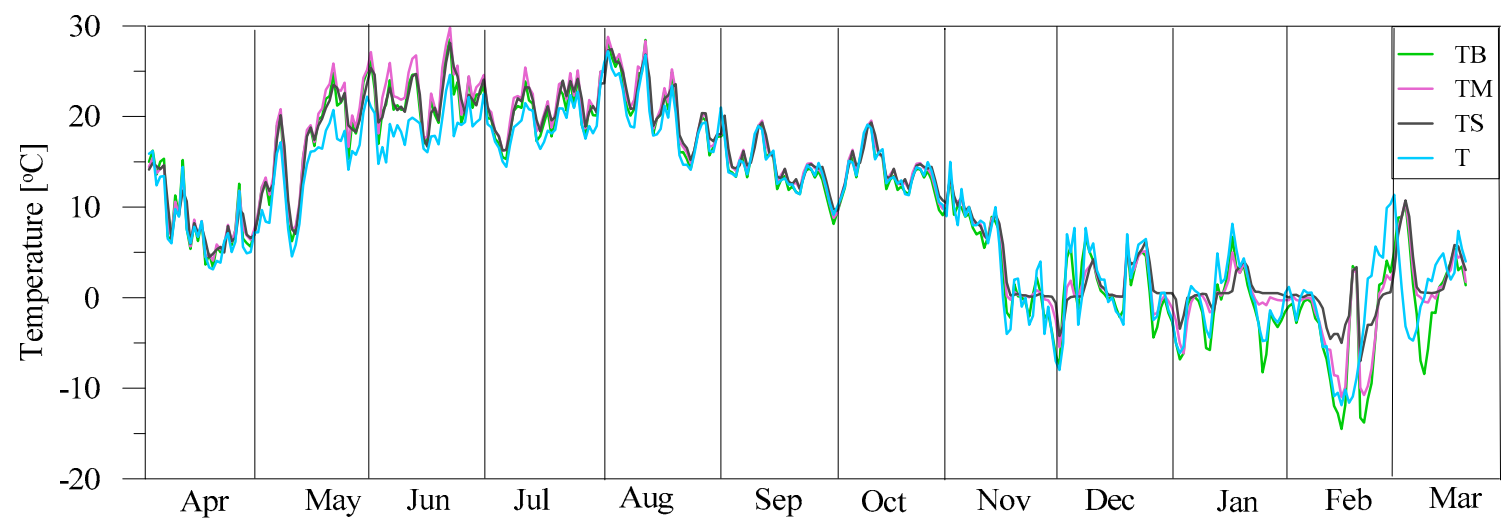

Figure 6. Daily variation in the temperature of the surface (TB), the vegetation mat (TM), the substrate (TS) and air (T) in the period of April 2017-March 2018 observed for GR 1. 
In the cool half of the year, i.e., from October-December and from January-March, an increase in temperature along with depth was observed. In the autumn period (October-December), the temperature of the biologically active surface was $6.9^{\circ} \mathrm{C}, 0.3^{\circ} \mathrm{C}$ higher than the air temperature (Figure 6). The temperature of the vegetation mat and substrate, was $0.7^{\circ} \mathrm{C}, 0.8^{\circ} \mathrm{C}$ higher than the air temperature. In the winter months (January-March), the highest temperature occurred in the substrate at a depth of $15 \mathrm{~cm}$ and ranged from $-7.0^{\circ} \mathrm{C}-10.0^{\circ} \mathrm{C}$. The average monthly temperature for winter at this depth was $0.96^{\circ} \mathrm{C}, 1.1^{\circ} \mathrm{C}$, higher than the air temperature. The active surface $\left(-1.3^{\circ} \mathrm{C}\right)$ and vegetation mat $\left(-0.7^{\circ} \mathrm{C}\right)$ were characterized by the lowest temperatures. The obtained daily values showed that the biggest differences during the day between the maximum and minimum temperature during the day, were obtained in May and June (the average temperature for the substrate in May was $7.9^{\circ} \mathrm{C}$ and in June $8.2^{\circ} \mathrm{C}$; for the vegetation mat the average temperature amplitude in May was $21.7^{\circ} \mathrm{C}$, in June $23.2^{\circ} \mathrm{C}$; for the active area, the average temperature amplitude for May was $22.2^{\circ} \mathrm{C}$, and $23.9^{\circ} \mathrm{C}$ in June) (Figure 7). The lowest differences in daily amplitude were recorded in December (the average temperature of the substrate was $1.6^{\circ} \mathrm{C}, 2.0^{\circ} \mathrm{C}$ for the vegetation mat, and $2.2^{\circ} \mathrm{C}$ for the biologically active area). The high variation in temperature, especially during summer periods, can result from the different properties of the green roof layers, i.e., the geotextile, drainage system and root protection membrane.

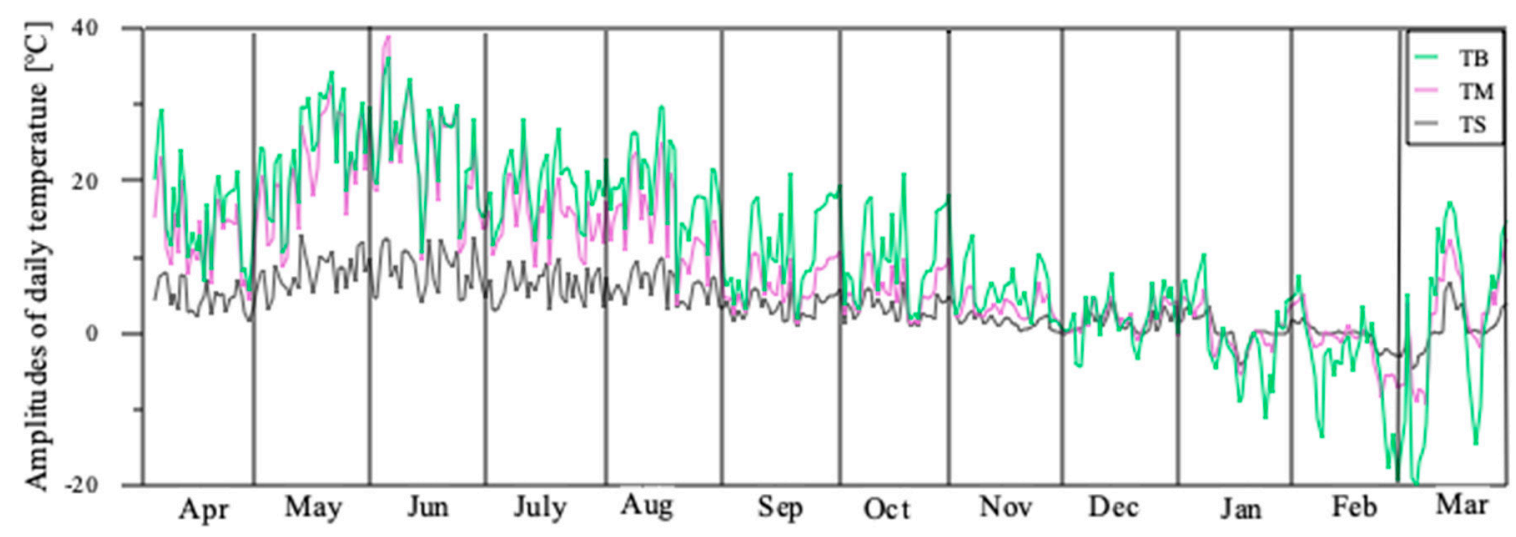

Figure 7. Daily temperature amplitudes $\left(\mathrm{T}_{\max }-\mathrm{T}_{\min }\right)$ : of the surface $(\mathrm{TB})$, vegetation mat $(\mathrm{TM})$ and substrate (TS) during the period April 2017-March 2018 for GR 1.

A typical temperature threshold for these elements is $50{ }^{\circ} \mathrm{C}$. Decreasing the temperature at the depth of the substrate may contribute to longer functioning of the materials used for roof construction.

The monitoring data obtained during this study enabled detailed analysis of the daily changes in temperature for the selected days during a summer and winter period, and two days with a rainy event. During the night and morning hours of a summer day (1 of August 2017) the surface temperature was lower than the air temperature, whereas the temperature of the vegetation mat was similar to the air temperature (Figure $8 \mathrm{a}$ ). The highest variation in temperature was noted for the active surface $\left(\mathrm{SD}=7.6^{\circ} \mathrm{C}\right)$ and the lowest for the substrate $\left(\mathrm{SD}=2.8^{\circ} \mathrm{C}\right)$. An increase of the active radiation (PAR) and air temperature was also confirmed by the statistically significant increase of the temperature of the active surface and vegetation mat $(\mathrm{p}<0.05)$. The Spearman rank correlation coefficient showed that over the course of a summer day, solar radiation has the highest influence on the temperature of the active surface $(r=0.89)$, the temperature of the vegetation mat $(r=0.67)$ and the temperature of the substrate $(r=-0.88)$. By analysing rainy days (19-20 of August 2017), it was observed that the occurrence of rainfall during a warm day caused a temperature decrease of the active surface and vegetation mat (by $20^{\circ} \mathrm{C}$ and $15^{\circ} \mathrm{C}$ respectively) over four hours, with a simultaneous drop in air temperature of $10^{\circ} \mathrm{C}$ (Figure 8b). During the occurrence of rainfall, the amount of radiation decreased, influencing the lower fluctuation of the air temperature. The next rainfall event, which occurred during the night and morning hours (data), did not cause considerable changes in the temperature in the 
active surface and vegetation mat. This was caused by the cool air conditions and an increase in the moisture content in the layers of green roof (Figure 8c).

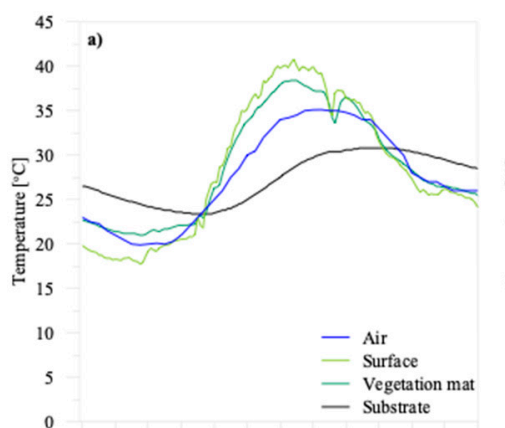

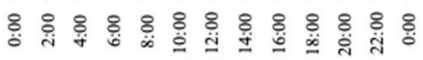
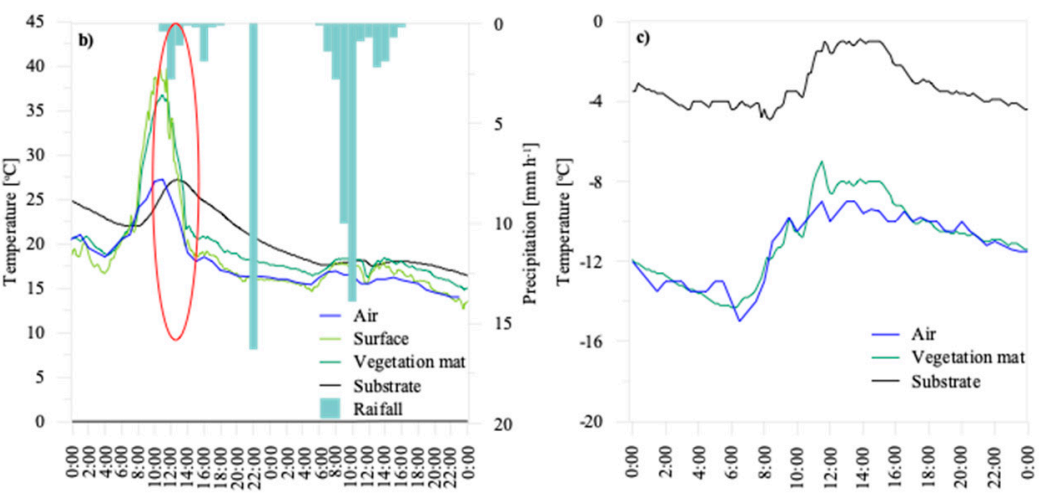

Figure 8. Daily temperature changes on a summer day (1 of August 2017) (a), rainy days (19-20 of August 2017) (b) and on a winter day (27 of February 2017) (c).

The lowest variation in temperature over the course of the two rainfall days was observed in the substrate $\left(\mathrm{SD}=3.15^{\circ} \mathrm{C}\right)$, whereas the highest were observed in the active surface $\left(\mathrm{SD}=5.71^{\circ} \mathrm{C}\right)$ and vegetation mat $\left(\mathrm{SD}=4.9^{\circ} \mathrm{C}\right)$; the standard deviation of the air temperature was $4.82^{\circ} \mathrm{C}$. An important aspect is the difference in temperature of $10{ }^{\circ} \mathrm{C}$ on the 19 of August prior to the occurrence of the rainfall between the air and the active surface as well as the mat with a moisture content below $\mathrm{pF} 4.2$ (Figure 9a). Such large differences in the green roof temperature were not observed on the 1 of August (Figure 8a), during which time the moisture content was within the optimal range. During a winter day (27 of February 2017), the smallest differences in temperature was noted in the substrate $\left(-2.3^{\circ} \mathrm{C}\right)$ (Figure 8c); this layer was characterized by the smallest standard deviation $\left(1.14{ }^{\circ} \mathrm{C}\right)$. The difference between the air temperature and the temperature of the substrate was $-7.9^{\circ} \mathrm{C}$. While the temperature of the vegetation mat fell under $-10^{\circ} \mathrm{C}$, that of the substrate did not fall below $-5{ }^{\circ} \mathrm{C}$.

\subsection{Influence of Environmental Factors on Temperature Changes in the Green Roof Profile}

In the vegetation period April-September 2017, the relationship between the temperature in the profile of an extensive green roof and meteorological parameters as well as the moisture content in the profile was determined. In the study period from the 1 of April to the 30 of September 2017, in all analysed months, the amount of rainfalls was higher than the multiannual average. The month which diverged significantly from the average of the multiannual period $(46.4 \mathrm{~mm})$ was September, during which the total rainfall reached $146.88 \mathrm{~mm}$. The maximum noted rainfall took place on the 17 of September 2017 and amounted to $54.10 \mathrm{~mm}$. During periods with very high rainfall, the amount of solar radiation was lower. In periods of low rainfall intensity, along with an increase in air temperature, low values of relative air humidity $(\mathrm{RH})$ occurred. The lowest values of relative humidity were recorded in June, and were the result of significant energy influxes, accompanied by high wind speeds and the lack of atmospheric precipitation. The maximum monthly values of evapotranspiration were obtained in the summer months (Figure 9b). The greatest differences P-E were noted in September $(+105.2 \mathrm{~mm})$. Over the course of the study, values of rainfall higher than evapotranspiration were noted in July and September. In the remaining months a shortage occurred, with the highest amount of $-40.9 \mathrm{~mm}$ in May. The average air temperature during the period of study (April-September 2017), was $15.9{ }^{\circ} \mathrm{C}$. The month with the highest average daily temperature was July $\left(19.5^{\circ} \mathrm{C}\right)$, and the lowest was April $\left(8^{\circ} \mathrm{C}\right)$. The daily distributions of this parameter in the vegetation period was dependent on the amount of energy reaching the active surface. In April, the values of the moisture content of the substrate were optimal (near the field capacity) and ranged from $0.25-0.27$. From the 11 of May the moisture content of the green roof began to decrease reaching the permanent wilting point moisture content at the end of May. From the 21 of May-26 of June 2017 the climatic water balance (CWB) was 
$-154.16 \mathrm{~mm}$, and was confirmed by the highly dry condition of the substrate and vegetation mate. It should be stressed that the vegetation mat was very sensitive during this period to precipitation (Figure 9a, green line). The rainfall occurring in this period, which was up to $10 \mathrm{~mm}$ with long breaks between rainfalls and high temperatures, did not cause an increase in the moisture content of the substrate. Rainfall in the period from the 26 of June- 8 of July 2017 (CWB $=34.29)$ caused an increase in the moisture content, which reached half of the total water holding capacity of the green roof. During the period between the 8-28 of July 2017 the moisture content of the substrate remained around half of the water holding capacity; the CWB in this period was $31.23 \mathrm{~mm}$. During the period of the 28 of July-20 of August 2017 the moisture content of the substrate began to fall to the level of a complete water deficit ( $\mathrm{pF}$ 4.2). During this time, the green roof was supplied with rainfall of $19.74 \mathrm{~mm}$, the air temperature remained above $20{ }^{\circ} \mathrm{C}$ and the average radiation was $400.3 \mathrm{Wm}^{-2}$. Rainfalls on the $28-29$ of August $2017(8 \mathrm{~mm}$ and $33.5 \mathrm{~mm}$ ) caused an increase in the moisture content to its optimal level (near field capacity), which was maintained until the end of September.

Negative correlations revealed that along with an increase in air temperature and radiation, the moisture content in the profile decreased; while an increase in $C W B$, relative humidity and wind speed caused an increase in moisture content in the profile $(\mathrm{p}<0.05)($ Table 2$)$.

Table 2. Spearman's rank correlation coefficients between meteorological parameters $(n=183)$ and moisture content in vegetation mat, and substrate (CWB-climatic water balance, RH-relative humidity, PAR - photosynthetically active radiation, T-air temperature, $\mathrm{W}$-wind speed, MM-mat moisture, MS-substrate moisture). Spearman correlation coefficient $r$ and probability $p$ (in brackets), p-values below 0.05 indicate statistically significant non-zero correlations at the $95.0 \%$ confidence level.

\begin{tabular}{cccccc}
\hline & CBW $[\mathrm{mm}]$ & RH [\%] & PAR $\left[\mathbf{W m}^{-2}\right]$ & T $\left[{ }^{\circ} \mathrm{C}\right]$ & W $\left[\mathrm{ms}^{-\mathbf{1}}\right]$ \\
\hline \multirow{2}{*}{ MM } & $0.5170(\mathbf{0 . 0 0 0 0 )}$ & $0.5720(\mathbf{0 . 0 0 0 0 )}$ & $\begin{array}{l}-0.6062 \\
\mathbf{( 0 . 0 0 0 0 )}\end{array}$ & $\begin{array}{l}-0.7136 \\
\mathbf{( 0 . 0 0 0 0 )}\end{array}$ & $0.1599(\mathbf{0 . 0 3 1 0 )}$ \\
\hline \multirow{2}{*}{$\mathrm{MS}$} & $0.4367 \mathbf{( 0 . 0 0 0 0 )}$ & $0.5002(\mathbf{0 . 0 0 0 0 )}$ & $\begin{array}{l}-0.5337 \\
\mathbf{( 0 . 0 0 0 0 )}\end{array}$ & $\begin{array}{l}-0.6873 \\
\mathbf{( 0 . 0 0 0 0 )}\end{array}$ & $0.1544 \mathbf{( 0 . 0 3 7 3 )}$ \\
\hline
\end{tabular}

In order to determine the relationships between the temperature in the green roof profile and the meteorological parameters as well as moisture content, the correlation coefficient was calculated for all months of the vegetation season in year 2017 (Table 3). In the entire vegetation period, a strong correlation between the temperature of the profile of a green roof and the temperature of the surface of an extensive type roof and the air temperature measured at a height of $200 \mathrm{~cm}$ was noted. These values ranged from 0.77-0.99. Generally, it can be noted that the highest values of the correlation coefficients were observed for the relationships between temperature of the active surface and the environmental parameters. The highest positive values of correlation between PAR and the temperatures in the profile of green roof were obtained for May and June ( $p<0.05$ for all levels). This tendency is rather expected because the highest average values of solar radiation were observed in these months ( $414 \mathrm{Wm}^{-2}$ in May and $444 \mathrm{Wm}^{-2}$ in June) and simultaneously this period was characterized by the low moisture content of the green roof. Significant correlations were not observed for PAR and any measured temperature of the green roof in April and September, which were months with the lowest values of solar radiation in the 2017 vegetation period ( $237 \mathrm{Wm}^{-2}$ in April and $147 \mathrm{Wm}^{-2}$ in September). 

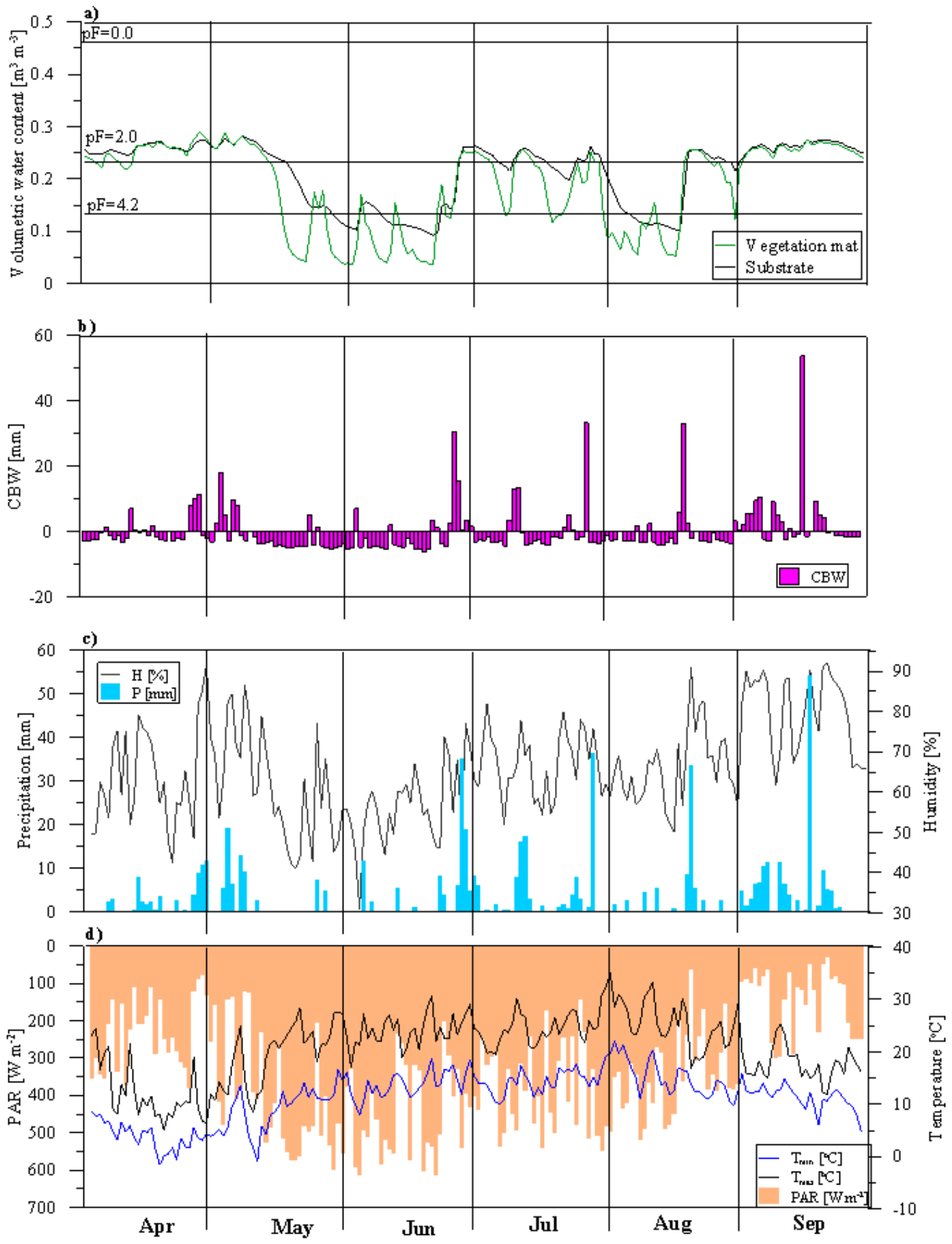

Figure 9. Average daily values of (a) moisture content in the vegetation mat and substrate, (b) climatic water balance, (c) atmospheric rainfall and relative humidity, and (d) air temperature (minimum and maximum) and active photosynthetic radiation in the vegetation period (April-September) 2017. 
Table 3. Spearman's rank correlation coefficients between environmental parameters $(n=30)$ and temperature in the profile of a green roof $(\mathrm{TB}$ - surface temperature, TM-mat temperature, TS — substrate temperature, CWB - climatic water balance, $\mathrm{RH}$ - relative humidity, PAR - photosynthetically active radiation, $\mathrm{T}$-air temperature, $\mathrm{W}$-wind speed, MM-mat moisture, MS-substrate moisture). Spearman correlation coefficient $\mathrm{r}$ and probability $\mathrm{p}$ (in brackets), $\mathrm{p}$-values below 0.05 indicate statistically significant non-zero correlations at the $95.0 \%$ confidence level.

\begin{tabular}{|c|c|c|c|c|c|c|c|}
\hline & $\mathrm{T}\left[{ }^{\circ} \mathrm{C}\right]$ & PAR $\left[\mathrm{Wm}^{-2}\right]$ & CBW [mm] & $\mathrm{W}\left[\mathrm{ms}^{-1}\right]$ & RH [\%] & MS $\left[\mathrm{m}^{3} \mathrm{~m}^{-3}\right]$ & $\mathrm{MM}\left[\mathrm{m}^{3} \mathrm{~m}^{-3}\right]$ \\
\hline T B & $\begin{array}{c}0.97 \\
\mathbf{( 0 . 0 0 0 0 )} \\
\end{array}$ & $0.16(0.3851)$ & $-0.42(0.0253)$ & $\begin{array}{c}-0.17 \\
(0.3532) \\
\end{array}$ & $\begin{array}{c}-0.30 \\
(0.1119) \\
\end{array}$ & $-0.64(\mathbf{0 . 0 0 0 5 )}$ & $-0.58(\mathbf{0 . 0 0 1 6 )}$ \\
\hline T M & $\begin{array}{c}0.95 \\
\mathbf{( 0 . 0 0 0 0 )}\end{array}$ & $0.08(0.6776)$ & $-0.36(0.0536)$ & $\begin{array}{c}-0.21 \\
(0.2556)\end{array}$ & $\begin{array}{c}-0.24 \\
(0.1928)\end{array}$ & $-0.62(\mathbf{0 . 0 0 0 8 )}$ & $-0.55(\mathbf{0 . 0 0 3 3 )}$ \\
\hline TS & $\begin{array}{c}0.88 \\
\mathbf{( 0 . 0 0 0 0 )}\end{array}$ & $0.01(0.9818)$ & $-0.29(0.1157)$ & $\begin{array}{c}-0.19 \\
(0.2978)\end{array}$ & $\begin{array}{c}-0.16 \\
(0.3812)\end{array}$ & -0.69 (0.0002) & $-0.57(\mathbf{0 . 0 0 2 0})$ \\
\hline \multicolumn{8}{|c|}{ May 2017} \\
\hline T B & $\begin{array}{c}0.99 \\
\mathbf{( 0 . 0 0 0 0 )}\end{array}$ & $0.66(\mathbf{0 . 0 0 0 3 )}$ & $-0.85(\mathbf{0 . 0 0 0 0 )}$ & $\begin{array}{c}-0.29 \\
(0.1153)\end{array}$ & $\begin{array}{c}-0.69 \\
\mathbf{( 0 . 0 0 0 1 )}\end{array}$ & $-0.79(\mathbf{0 . 0 0 0 0 )}$ & $-0.83(\mathbf{0 . 0 0 0 0 )}$ \\
\hline T M & $\begin{array}{c}0.99 \\
\mathbf{( 0 . 0 0 0 0 )}\end{array}$ & $0.66(\mathbf{0 . 0 0 0 3 )}$ & $-0.82(\mathbf{0 . 0 0 0 0 )}$ & $\begin{array}{c}-0.28 \\
(0.1210)\end{array}$ & $\begin{array}{c}-0.69 \\
\mathbf{( 0 . 0 0 0 2 )}\end{array}$ & $-0.80(\mathbf{0 . 0 0 0 0 )}$ & $-0.84(\mathbf{0 . 0 0 0 0 )}$ \\
\hline T S & $\begin{array}{c}0.96 \\
\mathbf{( 0 . 0 0 0 0 )}\end{array}$ & $0.56(\mathbf{0 . 0 0 2 0 )}$ & $-0.75(0.0000)$ & $\begin{array}{c}-0.23 \\
(0.2033)\end{array}$ & $\begin{array}{c}-0.63 \\
(\mathbf{0 . 0 0 0 6 )}\end{array}$ & $-0.83(\mathbf{0 . 0 0 0 0 )}$ & $-0.88(\mathbf{0 . 0 0 0 0 )}$ \\
\hline \multicolumn{8}{|c|}{ June 2017} \\
\hline T B & $\begin{array}{c}0.77 \\
\mathbf{( 0 . 0 0 0 0 )}\end{array}$ & 0.58 (0.0015) & $-0.31(0.0909)$ & $\begin{array}{c}-0.49 \\
\mathbf{( 0 . 0 0 8 3 )}\end{array}$ & $\begin{array}{c}-0.41 \\
\mathbf{( 0 . 0 2 9 1 )}\end{array}$ & $-0.09(0.6275)$ & $-0.29(0.1163)$ \\
\hline T M & $\begin{array}{c}0.69 \\
\mathbf{( 0 . 0 0 0 2 )}\end{array}$ & $0.67(\mathbf{0 . 0 0 0 3 )}$ & $-0.37(\mathbf{0 . 0 4 5 9 )}$ & $\begin{array}{c}-0.47 \\
\mathbf{( 0 . 0 1 1 5 )}\end{array}$ & $\begin{array}{c}-0.51 \\
(\mathbf{0 . 0 0 5 3 )}\end{array}$ & $-0.18(0.3068)$ & $-0.40(\mathbf{0 . 0 3 0 4 )}$ \\
\hline TS & $\begin{array}{c}0.76 \\
(\mathbf{0 . 0 0 0 0 )} \\
\end{array}$ & $0.38(\mathbf{0 . 0 3 9 7 )}$ & $-0.20(0.2901)$ & $\begin{array}{c}-0.30 \\
(0.1097)\end{array}$ & $\begin{array}{c}-0.24 \\
(0.1896)\end{array}$ & $-0.21(0.2370)$ & $-0.29(0.1213)$ \\
\hline \multicolumn{8}{|c|}{ July 2017} \\
\hline T B & $\begin{array}{c}0.94 \\
(\mathbf{0 . 0 0 0 0 )}\end{array}$ & $0.48(\mathbf{0 . 0 0 9 0 )}$ & $0.09(0.6364)$ & $\begin{array}{c}-0.44 \\
\mathbf{( 0 . 0 1 5 0 )}\end{array}$ & $\begin{array}{c}-0.21 \\
(0.2324)\end{array}$ & $-0.58(\mathbf{0 . 0 0 1 6 )}$ & $-0.56(\mathbf{0 . 0 0 2 1 )}$ \\
\hline T M & $\begin{array}{c}0.95 \\
(\mathbf{0 . 0 0 0 0 )}\end{array}$ & $0.41(\mathbf{0 . 0 2 4 8 )}$ & $0.15(0.3987)$ & $\begin{array}{c}-0.44 \\
\mathbf{( 0 . 0 1 6 0 )}\end{array}$ & $\begin{array}{c}-0.19 \\
(0.2970)\end{array}$ & $-0.64(0.0004)$ & $-0.60(0.0009)$ \\
\hline TS & $\begin{array}{c}0.95 \\
(\mathbf{0 . 0 0 0 0 )}\end{array}$ & $0.19(0.2901)$ & $0.24(0.1841)$ & $\begin{array}{c}-0.45 \\
(\mathbf{0 . 0 1 4 3 )}\end{array}$ & $\begin{array}{c}-0.01 \\
(0.9781) \\
\end{array}$ & $-0.69(\mathbf{0 . 0 0 0 2 )}$ & $-0.63(\mathbf{0 . 0 0 0 5 )}$ \\
\hline \multicolumn{8}{|c|}{ August 2017} \\
\hline T B & $\begin{array}{c}0.95 \\
(\mathbf{0 . 0 0 0 0 )}\end{array}$ & $0.47(\mathbf{0 . 0 0 9 6 )}$ & $-0.16(0.3870)$ & $\begin{array}{c}-0.12 \\
(0.5246) \\
\end{array}$ & $\begin{array}{c}-0.43 \\
\mathbf{( 0 . 0 1 8 2 )}\end{array}$ & $-0.58(\mathbf{0 . 0 0 1 6 )}$ & $-0.73(\mathbf{0 . 0 0 0 1 )}$ \\
\hline T M & $\begin{array}{c}0.95 \\
\mathbf{( 0 . 0 0 0 0 )}\end{array}$ & $0.43(\mathbf{0 . 0 1 9 6 )}$ & $-0.10(0.5814)$ & $\begin{array}{c}-0.11 \\
(0.5494)\end{array}$ & $\begin{array}{c}-0.40 \\
\mathbf{( 0 . 0 2 7 9 )}\end{array}$ & $-0.59(\mathbf{0 . 0 0 1 3 )}$ & $-0.74(\mathbf{0 . 0 0 0 1 )}$ \\
\hline TS & $\begin{array}{c}0.94 \\
\mathbf{( 0 . 0 0 0 0 )}\end{array}$ & $0.32(0.0754)$ & $-0.02(0.8954)$ & $\begin{array}{c}-0.06 \\
(0.7387) \\
\end{array}$ & $\begin{array}{c}-0.30 \\
(0.0999)\end{array}$ & $-0.56(\mathbf{0 . 0 0 2 0 )}$ & $-0.68(\mathbf{0 . 0 0 0 2 )}$ \\
\hline \multicolumn{8}{|c|}{ September 2017} \\
\hline T B & $\begin{array}{c}0.95 \\
\mathbf{( 0 . 0 0 0 0 )}\end{array}$ & $0.12(0.4924)$ & $0.17(0.3734)$ & $\begin{array}{c}-0.14 \\
(0.4656)\end{array}$ & $\begin{array}{c}0.05 \\
(0.7746) \\
\end{array}$ & $-0.26(0.1672)$ & $-0.24(0.1880)$ \\
\hline T M & $\begin{array}{c}0.92 \\
(\mathbf{0 . 0 0 0 0 )}\end{array}$ & $0.04(0.8377)$ & $0.22(0.2467)$ & $\begin{array}{c}-0.15 \\
(0.4284)\end{array}$ & $\begin{array}{c}0.14 \\
(0.4656) \\
\end{array}$ & $-0.29(0.1219)$ & $-0.27(0.1522)$ \\
\hline T S & $\begin{array}{c}0.90 \\
\mathbf{( 0 . 0 0 0 0 )}\end{array}$ & $0.05(0.8004)$ & $0.18(0.3409)$ & $\begin{array}{c}-0.03 \\
(0.8791)\end{array}$ & $\begin{array}{c}0.09 \\
(0.6412)\end{array}$ & $-0.31(0.0923)$ & $-0.30(0.1035)$ \\
\hline
\end{tabular}

The highest negative correlation was obtained for CWB and the temperature of the profile in the month of May, which was the month of the highest water deficit at $-40.9 \mathrm{~mm}$. In April, the CWB significantly affected the temperature of the active surface, whereas in June it affected the temperature of the vegetation mat. During the course of this study, the correlation coefficients were statistically significant for wind speed and the temperature of the profile in the months of June and July, whereas the correlation coefficients for relative humidity were statistically significant for May, June and August 
(the months with the lowest relative air humidity values of $60.5 \%, 56.8 \%$ and $64.3 \%$ respectively). The highest values of temperature correlation coefficients with moisture in the profile were obtained for May, which was the month with the highest water deficit in the green roofs. In the months of April, July and August, the correlation was significant, whereas in June, when the moisture content remained below the threshold for accessible water for the longest duration, the correlation was not significant. During the rainy September month $(C W B+101.65 \mathrm{~mm})$, the correlation coefficients were not statistically significant.

\section{Discussion}

Studies pertaining to innovative solutions in the building sector led to the evaluation of green roofs as a tool for lowering the temperature of urbanized areas and increasing energy savings, along with a number of other benefits in different fields. The study presents a broad analysis of the surface temperature of an experimental green roof in a moderate climate, accounting for the winter and summer periods. The first stage of the study involved comparing the surface temperature of extensive-type green roofs with a roof covered with bitumen. The greatest differences in surface temperature were obtained during the summer periods, at maximum temperature increases. At an air temperature of $30{ }^{\circ} \mathrm{C}$, the temperature of the conventional roof reached $53^{\circ} \mathrm{C}$ compared to $27^{\circ} \mathrm{C}$ for the green roofs. This confirms the studies of other authors showing that green roofs reduce the temperature of the roof surface which heated on hot days [15,51-54]. This increased peak and the high summer temperatures associated with it, have a significant influence on the durability of the roof membrane, and therefore its lifespan [55]. However, during warm periods it was found that the thermal behaviour of the green roof differs significantly from the conventional roof. It was found that the wet and covered surface of the soil is constantly cooler than the surrounding air during a representative warm day, as well as for most of the day in heat wave conditions. Compared to the conventional roof, the presence of a plant-layer system has created an inverted temperature profile. That shows the ability of the green roof to act as a passive cooling system, in the case of permanent lack of moisture availability [56]. In this study, changes in the temperature of a green roof profile covered with vegetation of the sedum type were analysed. Sedum plants are often used on green roofs in moderate climates due to their high resistance to drought [38,54]. Research carried out by [57] showed that in a Mediterranean climate, the cooling effect in the summer rather than the temperature moderating effect in the winter, is a more important function of the green roof. Therefore the sedum-only roof plots were a more effective choice, since the sedum achieved higher cover alone than in combination with annuals. In general, species that are able to maintain higher cover in the summer, and reduce substrate moisture more slowly during the spring, may be the best choice for green roofs that are used for their thermal benefits in regions with hot and dry summers. Plants, thanks to their specific properties (CAM—crassulacean acid metabolism), limit water loss during the day by closing their stoma apparatuses and reopen them at night $[53,54]$. Thanks to the CAM mechanism, plants are relatively resistant to drought and this can lead to a lowering of the temperature on summer days at night time. Some studies compared the cooling ability of different plant species, and found that succulent sedum species (such as S. acre L. and S. kamtschaticum Fisch. \& C.A.Mey.) provided the greatest cooling effect [58-61]. However, these studies were performed in wet and cool climates [58-60] or warm and rainy climates [58]. The cooling ability of different species may depend on the amount of groundcover they provide [61], and sedum may be particularly effective because it thrives in the dry conditions of a green roof. In the analysed summer days, the post-heating up temperature of the active surface at night was $0.3^{\circ} \mathrm{C}$ lower on days with optimal moisture content, but $0.9^{\circ} \mathrm{C}$ higher than the air temperature on days with critical moisture content $(\mathrm{pF}<4.2)$. Similar results were obtained by [53], where night cooling amounted to approximately $0.5^{\circ} \mathrm{C}$ and such relationships were not observed during dry periods. Some authors draw attention to the fact that the use of sedum is advised against in the moderate climate with winter temperatures falling below zero, as these plants are frost-sensitive and take long to colonize [59]. Moreover, monoculture is present in sedum, and the plants are not interesting as far as 
biological diversity and the function of a green roof are concerned. Instead of choosing green roofs with strictly sedum, some authors recommend the selection of a combination of plants with grasses and herbs [62,63]. In the case of this study, the plants initially present in the mat mixture (moss and herbs) did not survive the first year of test stands operation. The obtained results emphasize that the level of water content in the substrate is a variable which significantly influences the temperature of green roof surfaces, and is an effective medium for regulating temperature. Many authors have drawn attention to the fact that the consequential irrigation of green roofs significantly contributed to decreasing the temperature peaks of the surface; in the case of the a lack of irrigation, the results were accordingly varied [39]. The obtained results showed that the roof with vegetation can significantly contribute to the alleviation of UHI in the summer.

\section{Conclusions}

The obtained results comprise a picture of the course of temperature changes in the profile of a green roof over a long period of time in relation to environmental parameters such as precipitation, air temperature, wind speed, solar radiation and moisture content in the profile, characterized by different levels of influence.

1. A change in the direction of the profile temperature most frequently occurred in March from the surface deeper into the profile, and in September from the deeper layers towards the surface.

2. On a sunny day, the temperature reaction in the surface layer due to the solar factor is almost immediate. Due to the intense insolation during the day, the soil surface heats up the most and it is from this layer that heat is transferred to the deeper layers of the soil. On the other hand, at night this layer cools the fastest as a result of effective emanation, while a significantly higher temperature remains deeper within.

3. An analysis of the data showed that the course of daily changes in the temperature of the active surface and vegetation mat is usually higher than the range of changes in the air temperature. It is also important to account for the delay in the temperature in the substrate in relation to the air temperature.

4. An important regulator of the thermal conditions in the profile is atmospheric precipitation. It decreases the thermal gradient in soil, as well as temperature fluctuations over the course of a day as a result of an increase in moisture content following rainfall. Based on the obtained data, it was concluded that on a day with a wet surface, small fluctuations in temperature occurred over the course of the day as compared to a day characterized by low moisture content.

Author Contributions: The main conception of this article should be attributed to A.B. and T.G.; conducted field data collection A.B. and A.K.; statistical data analysis A.B., T.G.; writing of paper A.B., T.G., A.K., J.S.; all authors read, corrected and approved the final manuscript.

Funding: This research received no external funding

Conflicts of Interest: The authors declare no conflict of interest.

\section{References}

1. UN-Habitat Annual Report 2009; UN-HABITAT: Nairobi, Kenya, 2010; p. 62.

2. Kuriqi, A.; Ardiclioglu, M. Investigation of hydraulic regime at middle part of the Loire River in context of floods and low flow events. Pollack Period. 2018, 13, 145-156. [CrossRef]

3. Kuriqi, A. Assessment and Quantification of Meteorological Data for Implementation of Weather Radar in Mountainous Regions. Mausam 2016, 67, 789-802.

4. Kuriqi, A.; Ardiclioglu, M.; Muceku, Y. Investigation of Seepage Effect on River Dike's Stability under Steady State and Transient Conditions. Pollack Period. 2016, 11, 87-104. [CrossRef]

5. Perkins, S.E.; Alexander, L.V.; Narin, J.R. Increasing frequency, intensity and duration of observed global heatwaves and warm spells. Geophys. Res. Lett. 2012, 39. [CrossRef] 
6. Susca, T.; Gaffin, S.; Dell'Osso, G. Positive effects of vegetation: Urban heat island and green roofs. Environ. Pollut. 2011, 159, 2119-2126. [CrossRef] [PubMed]

7. Qiu, G.Y.; Li, H.Y.; Zhang QTChen, W.; Liang, X.J.; Li, X.Z. Effects of evapotranspiration on mitigation of urban temperature by vegetation and urban agriculture. J. Integr. Agric. 2013, 12, 1307-1315. [CrossRef]

8. Santamouris, M. Cooling the cities e a review of reflective and green roof mitigation technologies to fight heat island and improve comfort in urban environments. Sol. Energy 2014, 103, 682-703. [CrossRef]

9. Gaffin, S.; Rosenzweig, C.; Parshall, L.; Hillel, D.; Eichenbaum-Pikser, J.; Greenbaum, A.; Blake, R.; Beattie, D.; Berghage, D. Quantifying evaporative cooling from green roofs and comparison to other land surfaces. In Proceedings of the Fourth Annual Greening Rooftops for Sustainable Communities Conference, Awards and Trade Show, Boston, MA, USA, 11-12 May 2006; pp. 11-12.

10. Takebayashi, H.; Moriyama, M. Surface heat budget on green roof and high reflection roof for mitigation of urban heat island. Build. Environ. 2007, 42, 2971-2979. [CrossRef]

11. Castleton, H.; Stovin, V.; Beck, S.; Davison, J. Green roofs; building energy savings and the potential for retrofit. Energy Build. 2010, 42, 1582-1591. [CrossRef]

12. Bevilacqua, P.; Mazzeo, D.; Arcuri, N. Thermal interia assessment of an experimental extensive green roof in summer conditions. Build. Environ. 2018, 131, 264-276. [CrossRef]

13. Kumar, R.; Kaushik, S. Performance evaluation of green roof and shading for thermal protection of buildings. Build. Environ. 2005, 40, 1505-1511. [CrossRef]

14. Liu, K.; Baskaran, B. Thermal Performance of Green Roofs through Field Evaluation-Ottawa; Report no. NRCC-46412; National Research Council Canada, Institute for Research in Construction: Ottawa, ON, Canada, 2003.

15. Wong, N.H.; Chen, Y.; Ong CL Sia, A. Investigation of thermal benefits of rooftop garden in the tropical environment. Build. Environ. 2003, 38, 261-270.

16. Dohojda, M.; Podawca, K.; Witkowska-Dobrev, J. Termomodernization analyses of terraces located above existing apartments. E3s Web Conf. 2018, 44, 00032. [CrossRef]

17. Van Woert, N.D.; Rowe, D.B.; Andresen, J.A.; Rugh, C.L.; Fernandez, R.T.; Xiao, L. Green roofs stormwater retention: Effects of roof surface, slope, and media depth. J. Environ. Qual. 2005, 34, 1036-1044. [CrossRef]

18. Fioretti, R.; Palla, A.; Lanza, L.G.; Principi, P. Green roof energy and water related performance in the Mediterranean climate. Build. Environ. 2010, 45, 1890-1904. [CrossRef]

19. Pęczkowski, G.; Orzepowski, W.; Pokładek, R.; Kowalczyk, T.; Żmuda, R. Retention properties of the type of extensive green roofs as an example of model tests. Acta Sci. Pol. Form. Circumiectus 2016, 15, 113-120. (In Polish)

20. Baryła, A.; Karczmarczyk, A.; Brandyk, A.; Bus, A. The influence of a green roof drainage layer on retention capacity and leakage quality. Water Sci. Technol. 2018, 77, 2886-2895. [CrossRef]

21. MacIvor, J.S.; Lundholm, J. Performance evaluation of native plants suited to extensive green roof conditions in a maritime climate. Ecol. Eng. 2011, 37, 407-417. [CrossRef]

22. Abualfaraj, N.; Cataldo, J.; Elborolosy, Y.; Fagan, D.; Woerdeman, S.; Carson, T.; Montalto, F. Monitoring and Modeling the Long-Term Rainfall-Runoff Response of the Jacob K. Javits Center Green Roof. Water 2018, 10, 1494.

23. Brenneisen, S. The Benefits of Biodiversity from Green Roofs-Key Design Consequences; University of Applied Sciences: Wadenswil, Switzerland, 2003.

24. Oberndorfer, L.J.; Bass, B.; Coffman, R.; Doshi, H.; Dunnett, N.; Gaffin, S.; Koehler, M.; Liu, K.; Rowe, B. Green roofs as urban ecosystems: Ecological structures, functions, and services. BioScience 2007, 57, 823-833. [CrossRef]

25. Berndtsson, J.C. Green roof performance towards management of runoff water quantity and quality: A review. Ecol. Eng. 2010, 36, 351-360. [CrossRef]

26. Thuring, C.E.; Berghage, R., Jr.; Beattie, D.J. Green roof plant responses to different substrate types and depths under various drought conditions. HortTechnology 2010, 20, 395-401. [CrossRef]

27. Morgan, S.; Celik, S.; Retzlaff, W. Green roof storm-water runoff quantity and quality. J. Environ. Eng. 2012, 139, 471-478. [CrossRef]

28. Karczmarczyk, A.; Bus, A.; Baryła, A. Phosphate Leaching from Green Roof Substrates-Can Green Roofs Pollute Urban Water Bodies? Water 2018, 10, 199. [CrossRef] 
29. Baryła, A.; Karczmarczyk, A.; Bus, A. Role of Substrates Used for Green Roofs in Limiting Rainwater Runoff. J. Ecol. Eng. 2018, 19, 86-92. [CrossRef]

30. Dunnet, N.; Kingsbury, N. Planting Green Roofs and Living Walls; Timber Press: Portland, OR, USA, 2004; $254 p$.

31. FLL. Guidelines for the Planning, Construction and Maintenance of Green Roofing; The Landscape Development and Landscaping Research Society e.V: Bonn, Germany, 2008; 119p.

32. Getter, K.L.; Rowe, D.B. The role of extensive green roofs in sustainable development. HortScience 2006, 41, 1275-1285. [CrossRef]

33. Jones, H.G.; Stoll, M.; Santos, T.; de Sousa, C.; Chaves, M.M.; Grant, O.M. Use of infrared thermography for monitoring stomatal closure in the field: Application to grapevine. J. Exp. Bot. 2002, 53, 2249-2260. [CrossRef]

34. Stovin, V.; Vesuviano, G.; Kasmin, H. The hydrological performance of a green roof test bed under UK climatic conditions. J. Hydrol. 2012, 414, 148-161. [CrossRef]

35. Mattar, M.A.; Alazba, A.A.; Alblewi, B.; Gharabaghi, B.; Yassin, M.A. Evaluating and calibrating reference evapotranspiration models using water balance under hyper-arid environment. Water Resour. Manag. 2016, 30, 3745-3767. [CrossRef]

36. Spolek, G. Performance monitoring of three eco roofs in Portland, Oregon. Urban Ecosyst. 2008, 11, 349-359. [CrossRef]

37. Wadzuk, B.M.; Schneider, D.; Feller, M.; Traver, R.G. Evapotranspiration from a green-roof storm-water control measure. J. Irrig. Drain. Eng. 2013, 139, 995-1003. [CrossRef]

38. Jahanfara, A.; Drakea, J.; Sleepa, B.; Gharabaghi, B. A modified FAO evapotranspiration model for refined water budget analysis for Green Roof systems. Ecol. Eng. 2018, 119, 45-53. [CrossRef]

39. Monterusso, M.A.; Rowe, D.B.; Rugh, C.L. Establishment and persistence of sedum spp. and native taxa for green roof applications. HortScience 2005, 40, 391-396.

40. Cook-Patton, S.; Bauerle, T. Potential benefits of plant diversity on vegetated roofs: A literature review. J. Environ. Manag. 2012, 106, 85-92. [CrossRef] [PubMed]

41. Available online: http://www.xeroflor.pl (accessed on 26 March 2019).

42. Karczmarczyk, A.; Baryła, A.; Kożuchowski, P. Design and Development of Low P-Emission Substrate for the Protection of Urban Water Bodies Collecting Green Roof Runoff. Sustainability 2017, 9, 1795. [CrossRef]

43. Mularz, S.; Wróbel, A. Investigation of temperature distribution on a terrain surface using thermovision imaging. Arch. Photogramm. Cartogr. Remote Sens. 2003, 13b, 441-450. (In Polish)

44. Teemusk, A.; Mander, Ü. Greenroof potential to reduce temperature fluctuations of a roof membrane: A case study from Estonia. Build. Environ. 2009, 44, 643-650. [CrossRef]

45. Bevilacqua, P.; Mazzeo, D.; Bruno, R.; Arcuri, N. Surface temperature analysis of an extensive green roof for themitigation of urban heat island in southern mediterranean climate. Energy Build. 2017, 150, 318-327. [CrossRef]

46. Bac, S.; Rojek, M. Metodyka oceny stosunków wodnych obszarów rolniczych na podstawie danych klimatycznych. Zesz. Nauk. ART Olszt. 1977, 21, 13-24. (In Polish)

47. Allen, R.G.; Pereira, L.S.; Raes, D.; Smith, M. Crop Evapotranspiration Guidelines for Computing Crop Water Requirements; FAO Irrigation and Drainage, Paper nr 56; FAO: Rome, Italy, 1998.

48. Hargreaves, G.H.; Allen, R.G. History and evaluation of Hargreaves evapotranspiration equation. J. Irrig. Drain. Eng. 2003, 129, 53-63. [CrossRef]

49. Available online: https://pl.climate-data.org (accessed on 26 March 2019).

50. Sonne, J. Evaluating green roof energy performance. ASHRAE J. 2006, 48, 59.

51. Alexandri, E.; Jones, P. Developing a one-dimensional heat and mass transfer algorithm for describing the effect of green roofs on the built environment: Comparison with experimental results. Build. Environ. 2007, 42, 2835-2849. [CrossRef]

52. Heusinger, J.; Weber, S. Comparative microclimate and dewfall measurements at an urban green roof versus bitumen roof. Build. Environ. 2015, 92, 713-723. [CrossRef]

53. Solcerova, A.; van de Ven, F.; Wang, M.; Rijsdijk, M.; van de Giesen, N. Do green roofs cool the air? Build. Environ. 2017, 111, 249-255. [CrossRef]

54. Nagase, A.; Dunnett, N. Drought tolerance in different vegetation types for extensive green roofs: Effects of watering and diversity. Landsc. Urban Plan. 2010, 97, 318-327. [CrossRef] 
55. Schindlera, B.; Blausteina, L.; Vasla, A.; Kadasb, G.; Seifanc, M. Cooling effect of Sedum sediforme and annual plants on green roofs in a Mediterranean climate. Urban For. Urban Green. 2019, 38, 392-396. [CrossRef]

56. Dvorak, B.; Volder, A. Rooftop temperature reduction from unirrigated modular green roofs in south-central Texas. Urban For. Urban Green. 2013, 12, 28-35. [CrossRef]

57. Theodosiou, T.; Aravantinos, D.; Tsikaloudaki, K. Thermal behaviour of a green vs. a conventional roof under Mediterranean climate conditions. Inter. J. Sustain. Energy 2014, 33, 227-241. [CrossRef]

58. Heim, A.; Appleby-Jones, S.; Lundholm, J. Green roof thermal and stormwater performance comparisons between native and industry-standard plant species. Cities Environ. 2017, 9, 6.

59. Lundholm, J.; MacIvor, J.; MacDougall, Z.; Ranalli, M. Plant species and functional group combinations affect green roof ecosystem functions. PLoS ONE 2010, 5, e9677. [CrossRef]

60. MacIvor, J.; Margolis, L.; Perotto, M.; Drake, J. Air temperature cooling by extensive green roofs in Toronto Canada. Ecol. Eng. 2016, 95, 36-42. [CrossRef]

61. Benvenuti, S.; Bacci, D. Initial agronomic performances of Mediterranean xerophytes in simulated dry green roofs. Urban Ecosyst. 2010, 13, 349-363. [CrossRef]

62. Anderson, M.; Lambrinos, J.; Schroll, E. The potential value of mosses for stormwater management in urban environments. Urban Ecosyst. 2010, 13, 319-332. [CrossRef]

63. Butler, C.; Orians, C.M. Sedum cools soil and can improve neighboring plant performance during water deficit on a green roof. Ecol. Eng. 2011, 37, 1796-1803. [CrossRef]

(C) 2019 by the authors. Licensee MDPI, Basel, Switzerland. This article is an open access article distributed under the terms and conditions of the Creative Commons Attribution (CC BY) license (http://creativecommons.org/licenses/by/4.0/). 